\title{
Reluctant Warkior, Enthusiastic Peacekeeper: DOMESTIC LEgal REgulation OF CANADIAN Participation in ARMed Conflicts*
}

\author{
Ikechi Mgbeoji
}

\section{INTRODUCTION}

War is, by necessity, a savage and grisly business and the decision to participate in armed conflict is one of the most onerous any government can make. This paper examines the domestic norms and institutionalized procedures that constrain or guide the office of prime minister of Canada in deciding when and how to put Canada in a state of war or armed conflict. This question assumes greater importance and subtlety because in contemporary times, formal declarations of war, which in past would have followed intense parliamentary debates, now seem anachronistic. In modern times, states engage in armed conflicts, whether $^{\text {aggressive }^{1}}$ or defensive, without adopting the technical procedure of formally "declaring" war on perceived enemy-states. Indeed, so ubiquitous and recurrent is this phenomenon of "undeclared warfare" that some scholars have suggested that the technical concept of war (declaration of war) has been effectively replaced by the "factual concept of armed conflict." An obvious implication of this trend is

* This article is dedicated to my friend, Manjeet. It is a condensed and revised version of an earlier piece published by the Review of Constitutional Studies. See Ikechi Mgbeoji, "Prophylactic Use of Force in International Law: The Illegitimacy of Canada's Participation in 'Coalition of the Willing' Without United Nations Authorization and Parliamentary Sanction" (2003) 8 Review of Constitutional Studies 169. The usual disclaimers of responsibility apply.

On aggression, see Quincy Wright, "The Concept of Aggression in International Law" (1935) 29 American Journal of International Law 373

Contemporary scholarship regarding international law on warfare draws a distinction between war in the "technical" sense and war in the "material" sense. The former pertains to wars in which the state antagonists have formally declared war against themselves, even if there is no violent clash. The latter pertains to situations in which there is an eruption of hostilities between states, even in the absence of a declaration of war. For that Canadians may not realize that their troops may be engaged in armed conflicts somewhere without as much as a prior parliamentary debate on the necessity of otherwise of participating in an armed conflict.

Further, in the aftermath of the Cold War, incidents of use of force by states have increased. What is indeed very worrisome about this trend is that a whole range of dubious justifications has been asserted by states as necessitating the use of force. Some of the most ubiquitous justifications include the alleged need to remove perceived threats to international peace, ${ }^{3}$ purported danger to regional stability, ${ }^{4}$ or in some cases, the restoration a fuller analysis, see Yoram Dinstein, War, Aggression, and Self-defense, 3d ed., (Cambridge University Press, 2001) at 9; and Christopher Greenwood, "The Concept of War in Modern International Law" (1987) 35 International and Comparative Law Quarterly 283.

C.G. Fenwick, "When Is There a Threat to Peace?" (1967) 61 American Journal of International Law 753; Louis Henkin, "Conceptualizing Violence: Present and Future Developments in International Law" (1997) 60 Albany Law Review 571.

$4 \quad$ Emmanuel Ofuatey-Kodjoe, "Regional Organizations and The Resolution of Internal Conflicts: The ECOW AS Intervention in Liberia" (1994) 1:2 International Peacekeeping 1; Margaret Vogts, ed., Liberian Crisis and ECOMOG: A Bold Attempt at Peacekeeping (Lagos: Gabumo Publishing, 1992); George Nolte, "Restoring Peace By Regional Action: International Law Aspects of The Liberian Conflict" (1993) 53:3 Heidelberg Journal of International Law 603; and Alhaji M.S. Bah, "ECOWAS and Regional Peacekeeping: Unraveling the Political Cleavages" (2000) 15:3 International Insights 61. 
of "democracy" to some troubled states. In some other instances, states or groups of states have used force to alleviate alleged humanitarian crises. $^{6}$ This liberal construction of the right to resort to armed force in conflicts short of formal warfare threatens the stability of the global order. ${ }^{7}$

Another factor that raises a profound issue as to the legitimacy of such resort to armed force is the shrinking number of Canadians who participate in the domestic political processes leading to the emergence of governing institutions, especially at the federal level. In other words, an overwhelming number of "governing majorities" at the federal level are in fact governments that represent less than half of the actual number of votes cast at federal elections. Hence, the assumption that the Prime Minister of Canada represents the majority of the adult population of Canada is, at best, unfounded. Therefore, a regime that permits the Prime Minister to deploy Canadian troops to situations of armed conflict without parliamentary debate or approval, when in fact the governing party garnered less than a majority of the actual votes in the federal election, raises a significant question about the powers of the prime

\footnotetext{
Thomas M. Franck, "The Emerging Right to Democratic Governance" (1992) 86 American Journal of International Law 46; W. Michael Reisman, "Humanitarian Intervention and Fledging Democracies" (1995) 18 Fordham International Law Journal 794; Stephen J. Schnably, "The Santiago Commitment As a Call To Democracy: Evaluating the OAS Role in Haiti, Peru, and Guatemala" (1994) 25 University of Miami International Law Review 393; Karsten Nowrot \& Emily W. Schabacker, "The Use of Force to Restore Democracy: International Legal Implications of the ECOW AS Intervention in Sierra Leone" (1998) 14 American Journal of International Law 1; Malvina Halberstaam, "The Copenhagen Document: Intervention in Support of Democracy" (1993) 34 Harvard International Law Journal 163; Oscar Schachter, "The Legality of Pro-Democratic Invasion" (1984) 78 American Journal of International Law 645; and Pierre-Marie Dupuy, "The Place and Role of Unilateralism in Contemporary International Law" (2000) 11 European Journal of International Law 19.

Antonio Cassesse, "Ex Inuria Ius Oritur: Are We Moving Towards International Legitimation of Forcible Humanitarian Countermeasures in The World Community?" (1999) 10 European Journal of International Law 23.

Rudiger Wolfrum, "The Contributions of Regional Arrangements and Agencies to The Maintenance of International Peace and Security: Possibilities and Limitations" (1993) 53:3 Heidelberg Journal of International Law 576. A related problem is the increasing inclination of the UN Security Council to franchise out the authorization to states or groups of states. See John Quigley, "The 'Privatization' of Security Council Enforcement Action: A Threat to Multilateralism" (1996) 17 Michigan Journal of International Law 249; and Richard Falk, "The Haiti Intervention: A Dangerous World Order Precedent for the United Nations" (1995) 36 Harvard International Law Journal 341.
}

minister in relation to Canadian participation in armed conflicts.

Hence, a question that deserves careful analysis is whether domestic legal institutions and norms regulating use of force by states have developed to accommodate changes in domestic politics and international law with respect to emerging state practice regarding use of force. If the recent practice of the United Nations Security $\mathrm{Council}^{8}$ is an indicator of modern regulation of use of force by states, it stands to reason that domestic institutions and norms regulating use of force by states are in need of bold rethinking. ${ }^{9}$ This article briefly examines Canada's constitutional processes regulating use of force by Canada in its relations with other states. Although international law and norms influence the Canadian position on use of force in international law, this article focuses on the internal domestic law and institutions of Canada. I argue that domestic laws and institutions regulating use of force by Canada in its international relations are wholly inadequate. There is simply too much power in the office of the prime minister. Should he or she decide to commit Canada to war, it would seem that the only restraint on this power would come from the ballot boxes. Yet, on further analysis, the ballot boxes offer little solace. Since World War I, for example, Canada has had fifteen "majority" governments, but out of these

8 H. Freudenschuss, "Article 39 of The UN Charter Revisited: Threats to the Peace and the Recent Practice of the UN Security Council" (1993) 46 Austrian Journal of Public International Law 1.

9 Richard A. Falk, Legal Order in a Violent World (Princeton: Princeton University Press, 1968); Bruno Simma, "NATO, the UN and the Use of Force: Legal Aspects" (1999) 10 European Journal of International Law 1; A. Mark Weisburd, Use of Force: The Practice of States Since World War II (University Park, PA: Pennsylvania State Univeristy Press, 1997); Antonio Cassese, ed., The Current Legal Regulation On The Use of Force (Dordretch, The Netherlands: Klumer Academic Publishers, 1986); Noam Chomsky, "The Demolition of World Order" Harper's Magazine (June 1999) 1517; B.S. Chimni, International Law and World Order: A Critique of Contemporary Approaches (London: Sage Publications, 1993); Michael Reisman, "Unilateral Action and the Transformations of the World Constitutive Process: The Special Problem of Humanitarian Intervention" (2000) 11 European Journal of International Law 3; John Currie, "NATO's Humanitarian Intervention in Kosovo: Making or Breaking International Law" (1998) 36 Canadian Yearbook of International Law 303; Steve G. Simon, "The Contemporary Legality of Unilateral Humanitarian Intervention" (1993) 24 California Western International Law Journal 117; and Ian Brownlie, "Thoughts of Kind-Hearted Gunmen" in Richard B. Lillich, ed., Humanitarian Intervention and the United Nations (Charlottesville: University Press of Virginia, 1973) 139. 
governments, only four actually won a majority of the popular votes cast. The simple fact is that Canada has largely been ruled or governed by parties with arguably phony majorities and phony mandates. Hence, there is a need to rethink the domestic political process, particularly in relation to the power of the Prime Minister to place Canada in situations of armed conflict.

For purposes of clarity and ease of analysis, this article is divided into different parts. Part 1 examines the development of Canadian law and political practices on the use of force in international relations. For purposes of convenience, the analysis in Part 1 is developed through two themes. The first theme deals with Crown prerogative in matters of foreign relations and the impact of legislative and judicial developments on this difficult issue of law. The second theme extends the arguments beyond the legal doctrine of Crown prerogative to examine the legitimizing function of parliamentary involvement in decisions pertaining to the deployment of Canadian personnel to areas of international conflict. I divide the history of Canadian parliamentary involvement in matters of war into four epochs: the colonial era and Canada's position during World War I (1914-1919), independent Canada and World War II (1939-1945), the Korean Conflict (1950-1953) and the United Nations (UN) Charter (1945- present), and the first Gulf War (1991).

With respect to the pre-UN Charter era, Canada's domestic and international policy reflected the progressive ideals of those committed to outlawing war and promoted constraints on the ability of states to use force in non-defensive circumstances. More importantly, domestic Canadian parliamentary practices in the pre-UN Charter era evinced a cautious approach to the use of force or participation by Canada in international conflicts. Thus, the emergence of the UN, empowered to secure global peace and security, could be seen as an affirmation of Canadian skepticism towards belligerency and recourse to arms in settling conflicts. ${ }^{10}$

10 R. St. J. MacDonald, "The Relationship between International and Domestic Law in Canada" in R. St. J. MacDonald, Gerald L. Morris \& Douglas M. Johnston, eds., Canadian Perspectives on International Law and Organization (Toronto: University of Toronto Press, 1974) 88.
Regarding the UN Charter era, this watershed in the development of international law on use of force impacted Canadian domestic normative order on participation in acts of belligerency. Ultimately, Canada's original fidelity to the tenets of the UN Charter earned it a reputation as an honest broker. ${ }^{11}$ However, in the aftermath of Cold War politics, Canada's membership in the North Atlantic Treaty Organization (NATO) ${ }^{12}$ and geographical proximity to and special relationship with the United States of America has placed it in an awkward position on matters related to use of force. In navigating this treacherous and intricate situation, I argue that Canada's multilateralist traditions and commitments to the UN Charter can only have meaning if parliamentary and public participation in decisions on when, how, and where Canada participates in non-defensive armed conflicts are regarded as constitutional prescriptions rather than discretionary practices dependent on the mood swings of the prime minister. However, with a chronically weak opposition in Parliament, and a palpable democratic deficit arising from a "first-pass-thepost" system that distorts the preferences of Canadians, it would seem that the legitimacy of cabinet decisions in matters of use of force by Canada is very much in doubt.

\section{PART 1: CROWN PREROGATIVE AND JUDICIAL REVIEW OF CANADA'S PARTICIPATION IN ARMED CONFLICTS}

Originally, the position of the common law was that the royal prerogative was immune from judicial review. ${ }^{13}$ In Canada, the right to declare war is a prerogative of the Crown. ${ }^{14}$ The term "Crown," in the juridical sense, refers collectively to all the persons and institutions of the state that lawfully act in the name of the Queen. In other words, "Crown" is synonymous with the less grandiose term "government." Dicey described

Gibran Van Ert, Using International Law In Canadian Courts (The Hague: Klumer Law International, 2002).

12 North Atlantic Treaty Organization, 4 April 1949, 34 U.N.T.S 243 (entered into force on 24 August 1949).

13 China Navigation Co. v. Attorney-General, [1932] 2 K.B. 197 (C.A.).

14 Patrick Monahan, Constitutional Law (Concord, ON: Irwin Law, 1997) at 62. 
prerogative as the "residue of discretionary or arbitrary authority, which at any given time is left in the hands of the crown." ${ }^{15}$ Generally speaking, in matters related to the planning, preparation, initiation, and waging of war or of an armed conflict, the Crown is acting in virtue of its powers at both common law and outside of statutory control and authority. In effect, when the Crown acts in certain matters, it enjoys an unfettered and unconditional discretion. Even where the matter of going to war or engaging in armed conflict is tabled before Parliament for a debate and vote, there is no doubt that, legally, the Crown is not bound by the result of such a vote. A parliamentary debate on the wisdom, or lack thereof, of going to war is a matter of political politeness and tradition rather an event of any juridical consequence. However, judicial deference to Crown prerogative has yielded to a regime of measured judicial review. ${ }^{16}$ Hence, in modern times, the prerogative of the Crown is not a boundless power. As Professor Hogg has pointed out, "the prerogative [of the Crown] is a branch of the common law, because it is the decisions of the courts which have determined its existence and extent." 17

Although the scope and extent of the Crown prerogative has been somewhat limited by the courts ${ }^{18}$ and by some statutory provisions, ${ }^{19}$ there seems to be an unresolved question as to whether the Crown's prerogative to declare war and make peace on behalf of the Canadian state is, in modern times, subject to judicial review. In the celebrated GCCQ case ${ }^{20}$ the House of Lords, per Lord Roskill, placed the "defence of the realm" among those categories that "at present advised I

\footnotetext{
15 A.V. Dicey, Introduction to the Study of the Law of the Constitution, 10th ed. (London: Macmillan, 1965) at 424.

16 Chandler v. Director of Public Prosecutions, [1964] A.C. 763 at 810 (H.L.), Lord Devlin [Chandler v. D.P.P.]

17 Peter W. Hogg, Constitutional Law of Canada, 4th ed., looseleaf (Scarborough, ON: Carswell, 1997) at 1-14 [footnote omitted].

18 Operation Dismantle v. The Queen, [1985] 1 S.C.R. 441 [Operation Dismantle]

19 For example, under s. 32 (1) of the Canadian Charter of Rights and Freedoms, Part I of the Constitution Act, 1982, being Schedule B to the Canada Act 1982 (U.K.), 1982, c. 11 [Charter], cabinet decisions are reviewable. See Gérard V. La Forest, "The Canadian Charter of Rights and Freedoms: An Overview" (1983) 61 Canadian Bar Review 19.

20 Council of Civil Service Unions v. Minister for the Civil Service, [1985] 1 A.C. 374 (H.L.) [GCCQ].
}

do not think could properly be made the subject of judicial review." ${ }^{, 2}$ According to his Lordship:

Prerogative powers such as those relating to the making of treaties, the defence of the realm, the prerogative of mercy, the granting of honours, the dissolution of Parliament and the appointment of ministers as well as others are not, I think, susceptible to judicial review because their nature and subject matter are such as not to be amenable to the judicial process. The courts are not the place wherein to determine whether a treaty should be concluded or the armed forces disposed in a particular manner or Parliament dissolved on one date rather than another. ${ }^{22}$

Clearly, in England it is settled law that matters of foreign policy, including decisions by the Crown on participation in acts of belligerency, are beyond "judicial review" by the courts. ${ }^{23}$ Indeed, the British government is not even legally obliged to give reasons for its decisions on such matters pertaining to foreign policy, ${ }^{24}$ and the courts in England do not have the authority to rule upon the true meaning and effects of obligations applying only at the level of international law. ${ }^{25}$ This, however, should be distinguished from the narrower question of whether the Crown or its agents or officers may act with impunity on matters ostensibly within the rubric of Crown prerogative. In other words, in the exercise of its undoubted powers to initiate or plan armed conflicts, the Crown is not above the law. As pointedly noted by Lord Diplock in the $G C C Q$ case:

My Lords, that a decision of which the ultimate source of power to make it is not a statute but the common law (whether or not the common law is for this purpose given the label of "the prerogative") may

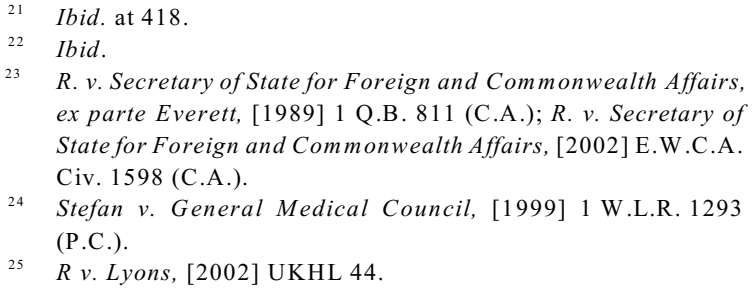


be the subject of judicial review on the ground of illegality is, I think, established by the cases cited by my noble and learned friend, Lord Roskill, and this extends to cases where the field of law to which the decision relates is national security, as the decision of this House itself in Burmah Oil Co. Ltd. v. The Lord Advocate, 1964 S.C. (H.L.) 117 shows. ${ }^{26}$

In effect, merely mentioning or invoking the mantra of Crown prerogative does not automatically dispose of the question. The courts would have to examine the nature of the issues raised and make a determination as to whether the issues raised pertain to a reviewable act or not. Where it is determined that the issues pertain to the disposition of the armed forces of the Crown, the decisions will be beyond judicial review. However, when in the exercise of such unreviewable prerogative power, neither the Crown nor its agents operate above the law of the land or binding international law. For example, no one may successfully litigate the question of whether the Crown was right to initiate an armed conflict, but the military forces of the Crown are not immune from prosecution if they commit war crimes in the course of participating in that armed conflict.

Turning back to the Canadian context, the question that arises is whether the position in English law is the same as in Canada. It would seem that the position in Canada regarding the ambit of Crown prerogative on matters of armed conflict is somewhat unclear. ${ }^{27}$ Legislative developments such as the National Defence $A c t^{28}$ and the War Measures Act (when it was still in effect) ${ }^{29}$ which encroach on Crown prerogative in matters regarding defence of the realm, have potentially extended the reach of judicial review. ${ }^{30}$

Supra note 20 at 411

Van Ert, supra note 11 at 93.

National Defence Act, R.S.C. 1985, c. N-5.

9 The War Measures Act, R.S.C. 1985, c. W-2. For a judicial interpretation of the act see R. v. Gray (1918), 57 S.C.R. 150. The act was in effect until 1988 when it was repealed by the Emergencies Act, S.C. 1988, c. 29. See Hogg, supra note 17 at 17-22.

30 As Professor Monahan observes: "[t]he courts have held that where a prerogative power has been regulated or defined by statute, the statute in effect displaces the prerogative and the Crown must act on the basis of the statutorily defined power" (supra note 14 at 63). See Attorney-General v. De Keyser's Royal Hotel Ltd., [1920] A.C. 508 (H.L.). Given that the
As in England, however, it is now settled law in Canada that where an exercise of Crown prerogative breaches written laws, the courts will not shirk from the duty of reviewing the Crown prerogative in issue. Canadian courts in Air Canada v. British Columbia (A.G.), ${ }^{31}$ Canada v. Schmidt ${ }^{32}$ United States of America v. Cotroni, ${ }^{33}$ and United States v. Burns ${ }^{34}$ have displayed unmistakable willingness to subject Crown prerogative to judicial review, particularly where such rights are protected by written law.

None of the authorities cited above deals squarely with the justiciability ${ }^{35}$ of executive decisions on Canadian participation in armed conflicts. To the best of my knowledge, the only case that may be of some relevance is the Supreme Court of Canada decision in Operation Dismantle $v$. The Queen. ${ }^{36}$ The appellants alleged that the decision of the federal cabinet to allow the United States to test cruise missiles in Canadian airspace violated their rights as enshrined in section 7 of the Charter of Rights and Freedoms. The majority of the Court dismissed the action on the grounds that the alleged increased threat of nuclear war, supposedly inherent in the tests, was predicated on speculative hypothesis. However, the Court was clear that cabinet-made foreign policy decisions of the government are justiciable where such decisions are alleged to infringe the rights of Canadians or persons resident in Canada. This would seem to accord with the distinctions made in respect of the law on the same subject in England.

However, the reasoning of the Court is somewhat difficult to follow. The plurality of the Court indicated that judicial restraint from review of such decisions is premised on the theory that proof of facts in support of justiciability of such claims would be nigh impossible. In the words of the majority of the Court:

provisions of the Emergencies Act relate to issues of domestic integrity, security and territorial integrity of Canada, I will avoid further analysis of this legislation and its possible implications for the subject under analysis.

1 [1986] 2 S.C.R. 539.

2 [1987] 1 S.C.R. 500

[1989] 1 S.C.R. 1469

4 [2001] 1 S.C.R. 283, 2001 SCC 7.

35 In the United States, the issue of justiciability of "political" questions is often vexed. See Coleman v. Miller, 307 U.S. 433 (1939).

36 Supra note 18. 
Since the foreign policy decisions of independent and sovereign nations are not capable of prediction, on the basis of evidence, to any degree of certainty approaching probability, the nature of such reactions can only be a matter of speculation; the causal link between the decision of the Canadian government to permit the testing of the cruise [missiles] and the results that the appellants allege could never be proven. ${ }^{37}$

These comments reflect the view of Lord Radcliffe in Chandler v. D.P.P. ${ }^{38}$ regarding the ability of the courts to review the complex host of factors that come into play when a parliamentary cabinet decides on whether to participate in international conflicts. However, Madam Justice Wilson anchored her decision on the self-made propriety of judicial review rather than the fictional inability of the courts to review such cabinet decisions. In her words:

[I]f we are to look at the Constitution for the answer to the question whether it is appropriate for the courts to "second guess" the executive on matters of defence, we would conclude that it is not appropriate. However, if what we are being asked to do is to decide whether the particular act of the executive violates the rights of the citizens, then it is not only appropriate that we answer the question; it is our obligation under the Charter to do so. ${ }^{39}$

It would therefore seem that a cabinet decision placing Canada in a state of armed conflict is not justiciable per se, but may be judicially scrutinized where there is evidence to support the claim that the execution of such a cabinet decision has infringed the rights of Canadians in circumstances that are not demonstrably justifiable in a free and democratic society. In sum, the Crown prerogative on matters of war remains intact, albeit with some modicum of judicial inroads.

In the absence of authority in support of judicial review of the Crown's prerogative to

\footnotetext{
Operation Dismantle, supra note 18 at 467.

Supra note 16.

Operation Dismantle, supra note 18 at 472 .
}

place Canada in armed conflicts, Crown prerogative in such matters may be politically constrained by parliamentary practices and democratic norms. Although these practices do not have the juridical character of customary law such as their equivalents have in international law, they embody accepted codes of conduct impacting on the legitimacy of decisions to situate Canada in armed conflicts. Crown prerogative in matters of armed conflicts, at least in the political sphere, is not a blank cheque. Theoretically, democracy and parliamentary practices are designed to curb executive rascality and impetuosity, particularly in matters as grave as use of force.

The absence of explicit constitutional constraints on Crown prerogative to declare war is derived from Canada's constitutional heritage (inherited from British constitutional conventions), whereby "political leaders could be trusted to exercise power in a restrained and responsible fashion." $" 40$ The reverse could be said to be the case in the United States where laws are designed to curb executive propensity for war. ${ }^{41}$ In the U.S., it is arguable that the separation of powers is stricter and thus the courts are institutionally leery of second-guessing the competence of Congress to declare war and make peace. ${ }^{42}$

The trusting relationship in Canada is probably reciprocal and is ostensibly founded on the Kantian notion that a parliamentary regime with the restraints of democratic and responsible governance would be less likely to use force in international relations unless there are clear, justifiable and compelling circumstances to warrant such momentous decisions. The theory is that only an irresponsible government would disregard informed public opinion or parliamentary participation when formulating

\footnotetext{
$40 \quad$ Monahan, supra note 14 at 17.

41 Louis Henkin, "Is There a 'Political Question' Doctrine?" (1976) 85 Yale Law Journal 597.

42 Martin H. Redish, "Abstention, Separation of Powers, and the Limits of the Judicial Function" (1984) 94 Yale Law Journal. 71; Fritz W. Scharpf, "Judicial Review and the Political Question: A Functional Analysis" (1966) 75 Yale Law Journal. 517; and Melville Fuller Weston, "Political Questions" (1925) 38 Harvard Law Review 296. The issue of justiciability of the so-called "political questions" other than war has met with mixed results in the United States. The presence of clear constitutional restraints on executive forays into belligerency has not stopped the government of United States from participating in wars without express Congressional declaration of war.
} 
decisions regarding deployment of Canadians to an armed conflict. If such a government were to be so reckless, there would probably be a heavy political price to pay for such folly.

With mounting evidence of increased power in the hands of the Prime Minister ${ }^{43}$ vis-à-vis an impotent and fractious opposition in the Canadian political system, it is doubtful whether Canada's imprudent trust in executive good faith on such an extraordinary matter as use of force in international relations is not unduly naïve and long-overdue for a rethink. Although the decision to use force in international relations may, in some circumstances, become a potential subject of judicial review, the importance of popular participation in parliamentary debates on issues of when, how, and where Canada uses force in international relations seems to be in the realm of political legitimacy rather than juridical validity.

Needless to say, to ensure that Canada is not heedlessly plunged into conflicts, a crucial factor is a vibrant, responsive, and alert Parliament. It therefore follows that in examining the probative value to be attached to the processes that yield Canada's decisions to play a role in international conflicts, regard must be had to certain factors including the quality of the debate in the Parliament, the power of the caucus, the potency of the opposition parties, and more importantly, the extent to which popular votes are reflected in the makeup of the Parliament itself. It is now apposite to evaluate the extent to which "majority" governments in Canada actually reflect the number of votes cast.

\section{PART 2: ARMED CONFLICTS AND CANADA'S DEMOCRATIC DEFICIT}

In theory, democracies are, inter alia, supposed to have good voting systems. A good voting system in turn yields democratic representation. Democratic representation must treat all votes cast equally, produce fair results, and make every vote count. Hence, where a voting system distorts the votes cast or fudges the

43 Some commentators have made legitimate observations to the effect that Canada is witnessing an increase of power in the hands of the Prime Minister and a "decay of Parliament." See Wes Pue, "The Chretien Legacy" Parkland Post 6:4 (Winter 2002) 1 . message sent by the voting public, such a democracy suffers a deficit of legitimacy. A sober analysis of the voting system in Canada vis-à-vis Canadian participation in armed conflicts reveals a shocking level of democratic deficit and gross distortion of voter preference. By force of logic, governments "elected" by distorted voter tabulation may be said to have questionable legitimacy and, consequently, the decisions of such governments to place Canada in armed conflict is hobbled by questions of legitimacy. Of the fifteen governments Canada has had since World War I, only four had true majorities. These were the governments elected in the federal elections of 1940, 1949, 1958, and 1984. In fact, the 1997 Liberal government was formed with only 39 percent of the popular vote. The long list of phony "majorities" at the federal elections include the $1930,1935,1945,1953,1968,1974$, 1980, 1988, 1993, 1997, 2000, and 2004 elections. The problem is that Canada maintains an antiquated and discredited voting system - called first-past-the-post. ${ }^{44}$

This system distorts the character of the actual votes cast, treats votes unequally, and wastes a considerable number of votes. How then does this voting system impact on Canada's participation in armed conflicts? Generally speaking, virtually all engagements of Canada in armed conflicts have been the product of parliamentary debates. Hence, if parliamentary debates and votes on matters related to armed conflict are to have normative weight, the composition of the Parliament must at the very least, represent the voter preference and public opinion of Canadians. It is now pertinent to examine Canadian parliamentary practices regarding use of force since 1914 to the present date.

\section{CANADA AND WORLD WAR I (1914-1918)}

In 1914, Canada was a colony of the United Kingdom. This historical factor heavily influenced the political legitimacy of the circumstances in

\footnotetext{
For a fuller discussion on Canada's democratic deficit see Jeffrey Simpson, The Friendly Dictatorship (Toronto, McClelland and Stewart Ltd., 2001); and Richard Simeon, "Recent Trends in Federalism and Intergovernmental Relations in Canada: Lessons for the UK?" (354) The Round Table (April $1,2000)$ at 231-43.
} 
which Canada participated in that war. ${ }^{45}$ It is therefore not surprising that the political processes preceding Canadian participation in World War I seemed to be a rehash of parliamentary developments and events in the United Kingdom. Accordingly, like other British colonies, Canada joined the war on 4 August 1914, the same day as the United Kingdom. It is significant that the colonial government in Canada took certain steps to legitimize, at least in the court of public opinion, Canada's participation in that war.

First, on 4 August 1914, the Canadian government "issued an Order-in-Council proclaiming that Canada was at war" ${ }^{\text {"46 }}$ with Germany. What is interesting here is that although Parliament was not sitting at the time when war broke out between Great Britain and Germany, Parliament was reconvened on 18 August 1914. It was on that day that after hearing the GovernorGeneral's speech in the Senate Chamber, the Canadian government issued an order-in-council proclaiming that Canada was at war and created war-related measures. ${ }^{47}$ Second, the decision to go to war was debated in the Parliament, and, in a normative sense, it is correct to say that there was popular input to the government's ultimate decision to join the conflict on the side of Great Britain. It would therefore seem that these measures conferred legitimacy on Canada's participation in the war of 1914-18. Shortly after the First World War, there was a heightened global movement towards arbitration of disputes and possibly, the outlawing of war. ${ }^{48}$ Greater emphasis was placed on the former and thus a decision as to whether to engage in war was to be predicated on a failure of honest and serious attempts at pacific settlement of disputes. This understanding was reflected in the Pact of the League of Nations.

\section{CANADA AND WORLD WAR II (1939-1945)}

45 Michel Rossignol, International Conflicts: Parliament, The National Defence Act, and the Decision to Participate (Ottawa: Research Branch, Library of Parliament, 1992), online: Library of Parliament, Parliamentary Information and Research Service $<$ www.parl.gc.ca/information/library/PRBpubs/bp303-e.htm>. 46 Ibid. at 2

47 House of Commons Debates (19 August 1914).

48 For an account of this epochal development in international law, see Hans Wehberg, The Outlawry of War, trans. by Edwin H. Zeydel (Washington: Carnegie Endowment for Peace, 1951).
By 1939, when the Second World War broke out, Canada was an independent state. However, formal political independence from Great Britain hardly severed or diminished existing economic, cultural and diplomatic ties between Great Britain and Canada. It was therefore natural that Canada would have strong sympathies with Great Britain when the latter declared war on Germany on 3 September 1939 after Germany had invaded Poland on 1 September 1939. It is hardly debatable that Canada's preference to join the war a few days after Great Britain was calculated to create the impression that Canada was an independent political entity and no longer tied to Great Britain. ${ }^{49}$ Consequently, Canada allowed ten days to elapse before jumping into the fray.

What is significant for the purposes of our analysis in this article is the domestic political process that culminated in the exercise of Crown prerogative to declare war on Germany. A few facts are crucial for our analysis. First, when the war started in Europe, Parliament was not in session. Indeed, Parliament was not scheduled to resume before 2 October 1939; however, owing to the emergency, Parliament was summoned on 7 September 1939. Great Britain had already been at war with Germany since 3 September 1939. After the Governor-General read the Speech from the Throne, parliamentary debates on the war were held from the 8 September until 10 September 1939. ${ }^{50}$ Both chambers of Parliament debated and approved the motion for formal declaration of war on Germany. ${ }^{51}$ What is very significant here is that parliamentary debate preceded the order-incouncil declaring war. This procedure was also followed when war was declared on Italy in $1940 .^{52}$ It is thus correct to assert that from 1939 to 1940, Canada followed a pattern of debate in Parliament before using force in its international relations. Interestingly, the 1940 federal election produced a true majority government.

However, this pattern of parliamentary debate prior to Canadian engagement in armed conflicts was broken in the course of a subsequent increase of belligerent states in that conflict and Canada's

\footnotetext{
J.L. Granatstein, Canada's War: The Politics of the Mackenzie King Government, 1939-1945 (Toronto: Oxford University Press, 1975).

50 House of Commons Debates (9 September 1939).

51 House of Commons Debates (11 September 1939).

52 House of Commons Debates (10 June 1940).
} 
use of force against Japan, Hungary, Romania, and Finland, countries which had aligned with Germany in World War II. With particular reference to Japan, Parliament had been adjourned since 14 November 1941 and was not scheduled to resume sitting until 21 January 1942. In the interval, on 7 December 1941, Japan bombed Pearl Harbor. Although there was a special sitting of the two houses, it was not for the purposes of debating any war resolution on Japan but to hear an "address to the Canadian Parliament by the British Prime Minister, Winston Churchill." Parliament resumed sitting on the date scheduled, 21 January 1942, and discussed a proclamation of war on Japan dated 8 December 1941. The proclamation purported that Canada had been at war with Japan as of 7 December 1941. For the first time in Canadian constitutional history, the country was engaging in conflict without prior parliamentary debate and approval. ${ }^{54}$

Similar proclamations that had been backdated to 7 December 1941 were made with respect to Hungary, Romania, and Finland, which had all joined the Axis coalition. Prime Minister Mackenzie King justified this untidy procedure with the argument that belligerency with respect to Hungary, Romania, and Finland were "all part of the same war." ${ }^{\text {55 }}$ Remarkably, records of parliamentary debates on this issue support the position of the Prime Minister, as none of the opposition parties questioned the normative import of the precedent set by Prime Minister King. Given that there were subsequent ratifications of the declarations of war against the allies of Germany, there is little doubt that the declarations of war on these allies of Japan and Germany would have been quickly approved if they had been tabled before Parliament prior to the actual engagement of hostilities.

As Rossignol observes, "Canadian public opinion accepted that Canada had no choice but to maintain its war effort against the continued aggression of Germany, Japan and Italy and their allies." "56 Even the pacifist Cooperative Commonwealth Federation (CCF) party that had maintained its opposition to Canadian parti-

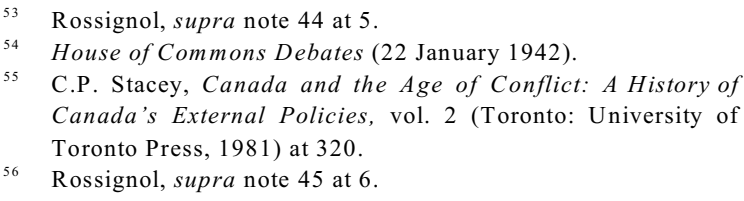

cipation in the war yielded ground on this issue. Speaking for the CCF party in Parliament on 10 June 1940, M.J. Coldwell observed that " $[\mathrm{t}] \mathrm{his}$ war is none of our seeking; it is thrust upon us. And we have no option it seems to me, but to accept the challenge and to go forward to ultimate victory. ${ }^{, 57}$ However, some Canadians, particularly Professor Frank Scott, were appalled at the government's politics in respect of parliamentary debate and retroactive approval of Canada's use of force in international relations. In a letter to Prime Minister Mackenzie King in 1939, Professor Scott complained that "a group of individuals took so many steps to place Canada in a state of active belligerency before Parliament met ... you very greatly limited Canadian freedom of action to decide what course to follow." 58

In reply to Professor Scott's quarrels with the politics of Canadian participation in some aspects of the war without prior parliamentary approval, some commentators like Michel Rossignol have argued that Professor Scott probably misread Canadian public opinion on the issue. According to Rossignol:

While Professor Scott thought that Parliament had been ignored, other Canadians would have been angered by any government delay in rallying to Britain's side as soon as war broke out. In other words, there were opposing views on the importance of Parliament's role in the process. The government, by insisting on reconvening Parliament before actually declaring war, had asserted Parliament's importance in the political process, and this was generally accepted by Canadians. ${ }^{59}$

It would seem that Rossignol has misconceived the kernel of Professor Scott's argument. Scott's grouse is with the procedure rather than presumptions about whether the public would have ultimately approved Canada's use of force. In any event, the Canadian public owes no gratitude to government for tabling such weighty issues for parliamentary discussion. The decision to use force in international relations is the most

\footnotetext{
House of Commons Debates (10 June 1940) at 653.

58 Stacey, supra note 55 at 10.

$59 \quad$ Granatstein, supra note 49 at 26; Rossignol, supra note 45 at 6.
} 
important decision and given that it is the public that bears the financial and emotional costs of such decisions, government is obliged to engage with public input. Secondly, although the Canadian government may, under conditions of an extreme emergency, place Canada in an active state of belligerency without prior parliamentary approval, there is doubt whether Canada's wars against Finland, Japan, Romania, and Hungary fell under this category. If Parliament had the time and patience to sit down and listen to Prime Minister Churchill, what stopped it from engaging in the more important task of debating Canada's proposed wars against Finland, Romania, and Hungary? More importantly, Rossignol's arguments seem to ignore the symbolic value of parliamentary participation in such momentous decisions as use of force by the state. Even if the outcome of such parliamentary process is a foregone conclusion, due process and legitimate governance require fidelity to such conventions.

\section{The UN Charter, Canada and the Korean CRISIS (1950-1953)}

The end of World War II ushered in a new era of international norms, particularly on the threat of use of force in international relations. In the course of parliamentary debates on the nature of Canada's participation in the Korean conflict, Prime Minister St. Laurent strongly argued:

Any participation by Canada in carrying out the foregoing resolution (the UN Security Council Resolution) - and I wish to emphasize this strongly - would not be participation in war against any state. It would be our part in collective police action under the control and authority of the United Nations for the purpose of restoring peace to an area where an aggression has occurred as determined under the charter of the United Nations by the security council, which decision has been accepted by us. ${ }^{60}$

From the foregoing, it is clear that both the Prime Minister and Parliament were clear that if Canada was to participate in the operation in the Korean

\footnotetext{
60 House of Commons Debates (30 June 1950) at 4459 [emphasis added].
}

peninsula, it was doing so as part of the collective police action under the auspices of the UN Security Council rather than as a belligerent act orchestrated by a group of states acting outside the authority of the United Nations Security Council. More importantly, there was a definite commitment on the part of the Prime Minister to submit the question of Canada's participation in the enforcement action to parliamentary debate. According to Prime Minister St. Laurent:

If the situation in Korea or elsewhere, after prorogation [of Parliament], should deteriorate and action by Canada beyond that which I indicated should be considered, Parliament will immediately be summoned to give the new situation consideration. ${ }^{61}$

Although Parliament did not "pass a motion specifically dealing with the government's decision concerning Canadian participation in U.N. police action in Korea," ${ }^{62}$ the desirability of Canadian participation in the enforcement action was raised in Parliament on 26 and 30 June 1950, and on 29 August 1950. Clearly, notwithstanding the added layer of the UN regime to the law on use of force by states, the Canadian political process made room for debate on whether Canada ought to participate in the Korean conflict. Thus, this era demonstrates how Canada adopted its tradition of domestic debate prior to, or immediately after, the use of force, to defer to the authority of the Security Council as the ultimate supervisor and executor in matters related to nondefensive use or threat of use of force in international relations. ${ }^{63}$

\section{The Gulf War, CanAdA, AND the LegitimaCy OF THE UN SECURITY COUNCIL (1991)}

Given that the enforcement action to remove Iraq from Kuwait (and no more) was sanctioned by the UN, there was no need for a declaration of war against Iraq. But there was need for a parliamentary debate of the issues. In addition, it was within the powers of the governor-in-council,

Ibid.

Rossignol, supra note 45 at 9.

${ }^{63}$ As Rossignol has argued, "Canada has always strongly supported the United Nations and championed collective action to ensure international peace." Ibid. at 11. 
without recalling Parliament, to authorize other actions taken by Canada in pursuance of the resolutions made by the UN Security Council. Moreover, since 1992, the United Nations Act ${ }^{64}$ and Special Economic Measures Act ${ }^{65}$ made it easier for the government to adopt and enforce emergency ${ }^{66}$ measures without Parliament being recalled. The determination of whether or not an emergency exists is the responsibility of Parliament. The troubling question here is whether these two legislative provisions have avoided domestic parliamentary debate and Canadian public participation in military activities.

Even when the Security Council has authorized such military measures, it would be desirable that the Canadian populace should have a place in the debates leading to the deployment of Canadian personnel to zones of conflict. Although Canada is obliged to comply with UN Security Council resolutions authorizing enforcement actions, it should also strive to scrutinize the motives and intentions of the permanent members of the Security Council, lest it sheepishly follow the Council in lending credibility to an illegitimate use of force. It is hardly debatable that the best way to ensure legitimate participation in UN enforcement actions is to subject any decision to send Canadian troops to any international conflicts, particularly those thickly enmeshed in power politics and the economic self-interests of members of the Security Council, to rigorous parliamentary and public debate.

\section{CONCLUSION}

This article has argued that Canadian democratic practices as evidenced in both pre-UN Charter and post-UN Charter regimes support the view that Canada has hardly participated in an international conflict without parliamentary debate, approval and/or ratification. In other words, Canadian participation in armed conflicts is often a function of parliamentary approval. The question raised by this practice or convention is whether such parliamentary approval is a legal

\footnotetext{
R.S.C. 1985, c. U-2.

5 S.C. 1992 , c. 17.

66 The National Defence Act defines emergency as "war, invasion, riot or insurrection, real or apprehended." Supra note 28, s. 2.
}

obligation on the part of the government. ${ }^{67}$ The short answer is that it is primarily a political obligation with implications for governmental legitimacy.

More importantly, Parliament has an undeniable role in reviewing the government's decision concerning Canadian participation in the use of force in international relations. Therefore, the question of Canadian participation cannot be a function of executive discretion. Canadian vigilance cannot be guaranteed unless Parliament is a potent and vibrant institution for the articulation of public concerns and interests. In this context, the chronic impotence of both the ruling party caucus and opposition parties in Parliament give reason for concern. As Professor Wes Pue has pointed out, Canadian democracy is increasingly becoming dysfunctional. ${ }^{68}$

With an electoral system designed to distort voter preferences, the development of de facto one-party government, the ascendancy of the prime minister and massive concentration of power in one man's control, and the decline of Parliament and caucus ${ }^{69}$ an effective parliamentary role in the decision to engage in armed conflicts is practically non-existent. A reappraisal of these shortcomings in Canadian democracy would not only reinforce the rights of the public to have their input considered through their elected representatives, but would also afford a needed measure of legitimacy and responsiveness in how and when Canada may engage in armed conflicts. $^{70}$

\section{Ikechi Mgbeoji}

Assistant Professor

Osgoode Hall Law School, York University

imgbeoji@osgoode.yorku.ca

\footnotetext{
Jim McNulty, "Liberals Owe Canadians Debate on Iraq" The Province (18 September 2002) A 14.

${ }_{68}$ W. Wesley Pue, "Bad Government: There Are No Friendly Dictators, Even in Canada" (2002) 10:1 Literary Review of Canada 14.

${ }^{69}$ Ibid.

70 Sheldon Alberts, "Let House Debate Role in Iraq War: Liberal MP's" National Post (15 January 2003) A1.
} 